\title{
Workers' Affective Commitment and Their Willingness To Perform Discretionary Work Behaviour: The Impact of Commitment-Oriented Human Resources Management Practices
}

\author{
Susan Zeidan \\ Victoria University, Australia
}

\begin{abstract}
This paper contributes to the development of the human resource management (HRM) literature through developing the linkages between HRM practices and employee attitudes and behaviours. It is widely believed that the implementation of high commitment human resource management (HRM) practices (e.g., training and development, communication, and participative decision making) can create strategic advantage for the organisation (e.g., Arthur, 1994; Delaney and Huselid, 1996). It is also suggested that HRM practices could shape employee attitudes and behaviours. However, the intervening mechanisms of this effect are yet to be examined. Researchers have pointed to the need to understand the means by which these practices exert their influence on employee commitment and other individual outcomes (Meyer and Smith, 2000).
\end{abstract}

Drawing on social exchange theory (Blau, 1964), this paper aims to address this need by developing a theoretical framework which explicitly links employee perceptions of HRM practices and important work outcomes via perceived fulfilment of the psychological contract. Drawing upon psychological contract theory, it is proposed that commitment HRM practices create a more positive psychological contract (and thus higher perceptions of fulfilment of the psychological contract). This will in turn, lead to increased affective commitment and enhanced organisational citizenship behaviours (OCB).

\section{Introduction}

As trends toward restructuring, mergers and acquisitions, e-commerce technology and global competition continue, organisations are increasingly pressured to make changes in the way their workforce is managed (Noer, 1993; Kissler, 1994; Coffey, Cook, and Hunsaker, 1994; Kreitner and Kinicki, 1995; Hitt, 1998, Cappeli, 1999). Underlying all of these changes, it becomes important to use HRM practices more effectively in gaining competitive advantage and in fostering organisational commitment and extra role behaviours. This is especially crucial as firms that learn to manage their human resources well will have a competitive edge over others for a long time to come (Wright, McMahan, and McWilliams, 1994). Further, those changes have led firms to seek to enhance their performance by finding new ways to compete, such as innovation, quality, and looking to different types of employment practices as sources of competitive advantages. 
One strategy that has been used in implementing new work practices has been termed the high commitment management approach (Wood and de Menezes, 1998, Whitener, 2001). Much of the research on high commitment human resource management practices was designed to test the link between commitment enhancing management practices and organisational-level performance (Snell and Dean, 1992; Arthur, 1992, 1994; MacDuffie, 1995; Delaney and Huselid, 1996; Youndt et al., 1996; Ichniowski et al., 1997; Appelbaum et al., 2000; Guthrie, 2001; Cappelli and Neumark, 2001; Bartel, 2004). Yet, it is still unclear if these HR practices also lead to desirable individual outcomes (GouldWilliams, 2004) with only a few recent studies that have examined the impact of these practices on the commitment of employees (Agarwala, 2003; Gould-Williams, 2004).

While this recent research suggests that these practices do have a positive impact on employee commitment, it is essential to understand the mechanisms by which these practices exert their influence on commitment and other individual outcomes (Meyer and Smith, 2000). In other words, research in this area leaves a key question unanswered concerning how high commitment HRM practices impact employee attitudes and behaviours, if indeed they do have an impact.

The purpose of this paper is to explore the possible positive impact of commitment-oriented HRM practices on employee outcomes. As previously discussed, the research question concerning what mechanisms or processes are responsible for translating high commitment HR practices into superior individual outcomes is yet to be answered. The objective of this paper therefore, is to address this gap by making a theoretical case, which suggests there may be interesting linkages between high commitment management and employee attitudes and behaviours via the psychological contract. Here, it is proposed that perceived psychological contract fulfilment would play an important role in mediating the relationship between commitment management practices and employee outcomes (specifically, affective commitment and $\mathrm{OCB}$ ).

To this end, the paper first presents an overview of the high commitment management approach to managing employees and psychological contracts. Following this, the paper discusses the potential linkages between high commitment management and psychological contracts. The paper then shifts focus to examine the concepts of commitment and OCB. Subsequently, propositions are made. Afterwards, the paper briefly outlines a tentative list of issues, which need to be addressed in order to increase our understanding of the links proposed. Finally, the paper concludes by suggesting that the relations between employees' evaluations of people centred management practices and their attitudes and behaviours are mediated by their perceptions of the fulfilment of the psychological contract.

\section{High Commitment Human Resource Management Practices}

Since the early 1990s, there has been a considerable growth in academic interest and research in a range of human resource management practices, termed 'high commitment' human resource management practices. High commitment management practices are built around efforts to manage organisational culture and warrant that workers function efficiently within and for this culture, and emphasise the importance of developing a sense of identity through involvement in shared organisational goals (Guest, 2002). The emphasis in the majority of research on high commitment management practices has been on how these practices improve organisational performance and profitability. In the human resource

Copyright (C) 2006 Victoria University. This document has been published as part of the Journal of Business Systems, Governance and Ethics in both online and print formats. Educational and non-profit institutions are granted a nonexclusive licence to utilise this document in whole or in part for personal or classroom use without fee, provided that correct attribution and citation are made and this copyright statement is reproduced. Any other usage is prohibited without the express permission of the management literature, researchers argue that the implementation of high commitment human resource management practices can be linked to enhanced organisational productivity and can create strategic and sustainable competitive advantage for the organisation (Weakland, 2001; Allen, Shore and Griffeth, 2003; Den Hartog and Verburg, 2004).

Although, there is still some disagreement 
about which practices should be included in any list of high commitment human resource practices (Purcell, 1999), these practices usually include, amongst others: communication, rigorous selection procedures, training and development, participative decision making, team working and rewards. Underlying these practices is the belief that organisations that develop their employees potential to the full, and provide them with the opportunity to make decisions that affect their work, will attain benefits in terms of improved performance. This premise that an emphasis on employee wellbeing is effective and valuable from a managerial position is not new. It is rather a continuation of deep-rooted approaches, such as that of the 'soft' human resource management approach (Beer et al., 1984).

These practices are thought to release untapped reserves of 'human resourcefulness' by increasing employee commitment, participation and involvement (Blyton and Turnbull, 1992) since an organisation's investment in building worker skills contributes to the 'psychological contract' of reciprocal commitment (Dore, 1992). Further, as indicated by Rousseau and Greller (1994), a more careful look at psychological contracts can guide HRM practices, enhance their impact on employees, and increase the ability to express commitments that can be kept while promoting effective organisations.

\section{Psychological Contracts}

The notion of psychological contract was first discussed in the 1960s with somewhat different conceptualisations, where it was used to characterize a series of mutual expectations between the employee and the organisation that govern the relationship between that employee and the organisation (see, Argyris, 1960; Levinson, Price, Munden, and Solley, 1962). Levinson et al. (1962) placed an emphasis on the idea that the psychological contract is an unwritten agreement between the employee and the organisation that focuses on the intangible aspects of the employment relationship. The construct then progressed to characterise the employment relationship, based on the beliefs employees or employers hold regarding their exchange relationship.

Many researchers have largely adopted the definitional framework outlined by Rousseau (1989, p. 123) who defined the psychological contract as:

'An individual's belief in the terms and conditions of a reciprocal exchange agreement between the focal person and another party. A psychological contract emerges when one party believes that a promise of future returns has been made, a contribution has been given, and thus an obligation has been created to provide future benefits'.

Scholars adopted this definition, (for example Guzzo and Noonan, 1994; Millward and Hopkins, 1998) with especially two points of agreement: psychological contracts are subjective and reciprocal. First, the psychological contract is a subjective perception in the sense that it refers to an individual's beliefs in the existence of an exchange agreement (McFarlane Shore and Tetrick, 1994). Second, the psychological contract is reciprocal, in the sense that it refers to an individual's belief regarding the mutual obligations of both parties to the relationship (Rousseau, 1990).

Psychological contracts have become a popular means for conceptualising and managing employment relations. Instead of limiting focus to the formal contract (e.g., hourly pay rates, working conditions), the psychological contract provides an opportunity to explore the processes and content of the employment that, in the words of Fox (1974), go 'beyond contract'. Psychological contracts are distinct from implied contracts, which are based on mutual understandings and which have greater legal connotations (Rousseau, 1989). The psychological contract, on the other hand, represents a set of practical and emotional expectations of benefits that employers and employees can reasonably have of each other (Argyris, 1960; Rousseau, 1990).

A psychological contract emerges when one party believes that a promise of future return has been made, for example, pay for performance, a contribution has been given (some form of exchange) and thus, an obligation has been created to provide future benefits (Robinson and Rousseau, 1994). That is, the employee's belief is based on the perception that an employer promise has been made (e.g., fair and 
competitive wages, job training, challenging and meaningful work) in exchange for an employee obligation (e.g., giving employer his or her time, energy, and technical skills) (Roehling, 1996; Rousseau and Tijoriwala, 1998). Unlike formal employment contracts, the psychological contract is not made once, but is rather revised throughout the employee's stay in the organisation (Rousseau and McLean Parks, 1993) and will change over time (McFarlane Shore and Tetrick, 1994). This is because; events in the form of new job assignments and organisational restructuring and downsizing may overlay new terms upon old ones (Robinson and Rousseau, 1994). Also, the more the employer and the employee interact, the greater the expectations, and contributions that might be included in the contract (Rousseau, 1989).

Perceived obligations and the extent to which those obligations are fulfilled represent the essence of the psychological contract (Rousseau, 1989). Perceived obligations set the parameters of the exchange whereas fulfilment of obligations captures behaviour within the exchange. Psychological contracts are subjective perceptions and expectations and involve only employee's beliefs; it is not necessary that the other party in the exchange relationship share these beliefs (Rousseau, 1989; Lucero and Allen, 1994; Shore and Tetrick, 1994). Psychological contracts reside only in the perceptions of individual employees, and are directed at the organisation at large. In addition, 'the subjectivity of the contract means that an individual can have a unique experience regarding his or her exchange relationship with an employer' (Rousseau and Tijoriwala, 1998, p. 680). Further, psychological contracts include obligations for which employees have reason to believe that a specific promise has been made (Morrison and Robinson, 1997). In addition, promises are not always explicitly stated, rather they also may be inferred from the employer's actions (Rousseau, 2001). This is not to say that the employer's perspective should be ignored. However, it is the employee perceptions that will influence his or her attitudes and behaviour in reacting to the fulfilment or non-fulfilment of his or her psychological contract. Employees who fulfil their obligations to their organisation feel entitled to receive certain benefits. These entitlements may have been explicitly stated by the organisation, or implied and assumed by the employee (McLean Parks, Kidder, and Gallagher, 1998).

Morrison and Robinson (1997, pp. 228-229) summarise the defining characteristics of psychological contracts as follows: (1) they are the internal cognitions of individuals formed and held individualistically, (2) they are founded upon perceived promises 'where a promise is ... any communication of future intent', (3) they are held by individuals with respect to the employing organisation in the abstract. That is, they are not formed with respect to any specific agent within the organisation, and (4) they can be transactional or relational in nature. Although individuals may hold both elements in cognition at the same time, their formation, impact and dynamics are different.

In essence, the psychological contract reflects employees' perceptions of the mutual expectations and obligations between themselves and their employer. Obviously, such a definition suggests a firm's human resource management practices allow an organisation to communicate to employees the proposed contract, including the organisation's promises on the one hand (e.g., to train, promote and reward), and expectations on the other (e.g., to perform to some standard, to learn new skills) (Guzzo \& Noonan, 1994). High commitment management practices, in particular, allow an organisation to foster the contemporary psychological contract, one that fits with the modern day employee's work preferences and values (e.g., development of skills, greater participation, work-life balance).

\section{High Commitment Management and Psychological Contracts}

Theoretically, it is assumed that high commitment HRM practices create the conditions for employees to become highly involved in the organisation and identify with its overall goals (Wood \& DeMenzies, 1998) - in other words, by increasing their employees' commitment to the organisation (Whitener, 2001). Highly committed employees are expected to perform consistently at a high level, as well as show initiative and a willingness to expend extra effort towards reaching organisational goals (Walton, 1985). In effect, commitment oriented HRM practices influence the quality of the social exchange relationship between employees and the employing organisation. Based on social exchange theory (Blau, 
1964 ) and the norm of reciprocity (Gouldner, 1960), Eisenberger, Fasolo, and Davis-La Mastro (1990) suggested employees develop a sense of obligation to respond favourably (e.g., performing well, remaining with the organisation, etc.) to favourable treatment from their employer. HRM practices are one means by which an organisation is able to demonstrate its assessment of and commitment to employees. Thus, high commitment HRM practices have the potential to favourably influence perceptions of what the organisation is like to work for, and in turn, the nature of the psychological contract and their perceptions of the fulfilment of the psychological contract.

On the basis of the evidence presented in the human resource management literature, it appears that research on HRM fails to provide an adequate basis for understanding the association between HRM and the employee. This failure is highlighted by a number of researchers (Gibb, 2001; Gallie et al., 2001), who believe that the scarcity of research into employee reactions to HRM needs to be addressed. Such an approach is congruent with Guest's $(1999$, p. 5) observation that 'any concern for the impact of HRM should be as much with outcomes of relevance to workers as to business'.

Grant and Shields (2002) also indicate that the need for valid and accurate assessment of employee reactions to HRM has never been greater. They further suggest that a possible answer to employee reactions to HRM may be found in the psychological contract. Grant and Shields (2002, p. 325) argue, 'the psychological contract helps explain why, provided management and employee expectations are met and promises and obligations are fulfilled, a host of HRM practices might be accepted by employees and why they might record a positive reaction. Conversely, if expectations or promises and obligations are not met, then in the context of a broken psychological contract we are able to understand why workers might record a negative reaction to HRM'.

Guzzo and Noonan (1994) argued that an employee's assessment of the status of his or her psychological contract is a result of the systematic, deep processing of what HRM practices convey to that employee. Prior research has suggested HRM practices as significant antecedents shaping the nature of the psychological contract (see for example, Rousseau \& Greller, 1994; Sels, Jansens \& Van den Brande, 2004). Yet, none of the empirical studies to date have examined employee perceptions of psychological contract fulfilment as a mediator between high commitment HRM practices and different work outcomes; that is, the mechanisms by which these practices relate to affective commitment, and organisational citizenship behaviour are yet to be examined. Hence, future research is needed and would benefit from testing the theoretical model put forward in this paper.

Herein it is proposed that more favourable psychological contracts will develop in organisations that implement high commitment management practices, or other similarly progressive people management techniques. In essence, high commitment HRM practices communicate to employees that they are valued by the organisation and that the organisation is committed to them. As such, it is expected that when employees' perceptions of the management practices employed in their organisation is higher, that will influence their perceptions of psychological contract fulfilment, such that these perceptions are higher as well. It is also proposed that higher perceptions of psychological contract fulfilment lead to more positive attitudes and behaviours such as, increased affective commitment, and enhanced organisational citizenship behaviours. These work outcomes are briefly discussed next.

\section{Affective Commitment}

Affective commitment is one specific form of organisational commitment, which has been considered the most beneficial in enhancing organisational effectiveness. This form of commitment emphasizes an individual's identification and involvement in the organisation (Porter, Steers, Mowday and Boulian, 1974). Employees high in affective commitment demonstrate emotional attachment, identification with and involvement in the organisation. This would explain why these employees are less likely to engage in withdrawal behaviour and more likely to accept change (Meyer and Allen, 1997; and Iverson and Buttigieg, 1999). 
Consistent and strong correlations have been found between work experience variables and affective commitment across a number of studies. For instance, affective commitment has been positively correlated with job challenge, degree of autonomy, and variety of skills used by the employees in different samples of employees (Colarelli et al, 1987; Dunham et al. 1994). Additionally, numerous researchers have examined the consequences of affective commitment and have found it to be associated with behaviours such as in-role job performance, and extra-role behaviour (e.g., Meyer, Paunonen, Gellatly, Goffin, and Jackson, 1989).

Research suggests that compared to continuance and normative commitment, affective commitment correlates significantly with a wider range of outcomes and correlates more strongly with any given outcome measure (see, Mathieu and Zajac, 1990; Tett and Meyer, 1993). For example, Stanley, Meyer, Topolnytsky and Herscovitch (1999) conducted a series of meta-analyses to examine the correlations between commitment and turnover intention, absenteeism, job performance, and organisational citizenship behaviour. They found that all three components of commitment correlated negatively with turnover intention. However, the magnitude of the correlations differed - the strongest correlation was with affective commitment, followed by normative and continuance commitment. In addition, affective commitment correlated more strongly than did normative and continuance commitment with measures of absenteeism, and organisational citizenship behaviour. Moreover, in contrast to affectively committed employees, continuance and normatively committed employees demonstrate reduced levels of citizenship behaviours and lack the initiative to perform tasks that go beyond their job descriptions (Shore and Wayne, 1993).

According to Meyer and Herscovitch (2001), a possible explanation for why affective commitment correlates with a wider range of outcomes is that, when commitment is accompanied by a mind-set of desire (such as the case with affective commitment), the behavioural consequences of commitment are perceived by the individual to be broader than when commitment is accompanied by a mind-set of provided cost or obligation. The authors argue that an individual with high affective commitment towards an organisation is more likely to consider the best interests of that organisation than someone with high continuance or normative commitment. They further recommend that wherever possible, it is desirable to foster affective commitment. Additionally, Meyer, Allen, and Smith (1993) suggest that a person who is affectively committed might be more likely than someone who is not so attached to keep up with developments in the occupation, and to join and participate in relevant associations. Furthermore, Meyer and Allen (1997) state that affective commitment is the most desirable form of commitment and the one that organisations are most likely to want to instil in their employees.

\section{Organisational Citizenship Behaviour (OCB)}

Organisational citizenship consists of behaviours that extend beyond specific role requirements, with the stipulation that such behaviours are performed voluntarily without expectation of material or social rewards (Brief and Motowidlo, 1986). That is, OCBs are those behaviours that are not explicitly recognized by an organisation's reward system and that promote organisational effectiveness. Organ (1988, p. 4) defined organisational citizenship behaviour (OCB) as:

'... Individual behaviour that is discretionary, not directly or explicitly recognized by the formal reward system, and that in the aggregate promotes the effective functioning of the organisation."

Thus, according to Organ's (1988a) definition, citizenship behaviour has at least three characteristics: a) the behaviour is discretionary; (b) the behaviour is not directly or explicitly recognized by the formal reward system; and (c) in the aggregate, the behaviour promotes the effective functioning of the organisation.

Interest in OCB can be traced back to Barnard's (1938) concept of the 'willingness to cooperate' and Katz's (Katz, 1964; Katz and Khan, 1966) distinction between dependable role performance and 'innovative and spontaneous behaviours'. Organ and his colleagues first coined the term 'organisational 
citizenship behaviour' in the early 1980s (e.g., Bateman and Organ, 1983; Smith, Organ and Near, 1983). Over the past two decades, interest in behaviour that generally fits the definition of OCB has increased dramatically (see Podsakoff et al., 2000), and OCB has been the subject of numerous studies (e.g., Organ and Konovsky, 1989; MacKenzie, Podsakoff and Fetter, 1991; Niehoff and Moorman, 1993; Organ and Ryan, 1995; Lievens and Anseel, 2004), with few studies regarding the relationship between OCB and the psychological contract.

OCB tends to increase the organisation's efficiency and effectiveness (Rioux and Penner, 2001). Research indicates that OCB adds significantly to overall positive performance evaluations and reward recommendations (Allen and Rush, 1998). Hence, it is critical for organisations to ensure that their employees engage in OCB since organisations depend on OCB in order to run smoothly and effectively (Barnard, 1938; Katz, 1964). When an employee perceives that his/her organisation has failed to fulfil one or more promised obligations, he/she is likely to reciprocate by reducing his/her affective commitment, and extra-role performance (Robinson and Morrison, 1995; Robinson, 1996). On the other hand, higher employee perceptions of fulfilment of the psychological contract are bound to increase employees' commitment and organisational citizenship behaviours.

\section{Propositions}

Subsequent to the previous discussion, the following propositions are made regarding commitmentoriented HRM practices, perceived psychological contract fulfilment, affective commitment and organisational citizenship behaviours.

Proposition 1. High commitment work practices are positively related to affective commitment.

Proposition 2. High commitment work practices are positively related to OCB.

Proposition 3. Perceived psychological contract fulfilment is positively related to affective commitment.

Proposition 4. Perceived psychological contract fulfilment is positively related to OCB.

Proposition 5. Perceived psychological contract fulfilment mediates the relationship between the high commitment management work practices and affective commitment

Proposition 6. Perceived psychological contract fulfilment mediates the relationship between the high commitment management work practices and OCB.

\section{A Research Agenda}

While the previous sections have suggested a model that explains the process through which high commitment management influences employee attitudes and behaviours, this model requires to be empirically substantiated. The paper therefore concludes by considering some relevant issues, which would need to be considered by any research conducted to evaluate the model.

First, the theoretical model presented in this paper needs to be more fully evaluated and tested. Second, while some research has shown that HRM practices can influence commitment level, further research is required in this area. Third, further empirical research is required into the ways in which contemporary changes in the employment relationship are affecting the psychological contract of workers. Knowledge on these questions can be developed and advanced by both HRM analysts conducting empirical research and by HRM practitioners.

Another interesting avenue for future research is the extent to which individual perceptions match up with objective organisational reports. This has important practical implications for managers and organisations desiring to use high commitment HRM practices to increase employee affective commitment and discretionary work behaviours. Future research could also explore the possible 
moderating effects of the saliency employees attach to specific obligations in how they react to contract breach or fulfilment.

\section{Conclusions}

HRM practices have been regarded as effective tools for enhancing organisational commitment. Yet to date most empirical research examining high commitment management practices has been more concerned with investigating the relations between these practices and organisationally relevant outcomes rather than examining whether these practices actually influence commitment, and employee behaviour, or the mechanisms by which such an influence occurs. This is in spite of early calls suggesting that research that directly investigates the connection between HRM practices and employee re-evaluations of the extent to which their psychological contracts are fulfilled is especially needed (Guzzo and Noonan, 1994). Thus this paper put forth a theoretical model linking high commitment management practices with individual work outcomes via employee perceptions of the fulfilment of the psychological contract.

By understanding, and more importantly, attempting to manage the psychological contract, organisations are better able to ensure more positive work outcomes from their employees. HRM personnel will increasingly find that their expectations and those of employees are not congruent. To better communicate expectations, HRM personnel must take steps to understand employees' perceptions of the content of the psychological contract and from this alter the terms of the contract where circumstances permit. In this paper, it was suggested that high commitment HRM practices might indeed foster more positive psychological contracts than what traditional HRM practices can bring, and that such practices also lead to higher perceptions of fulfilment of the psychological contract. These perceptions might in turn result in more positive individual work outcomes. In conclusion, future research in this area will help further our understanding of the potential effects of high commitment management practices on psychological contracts and employee level outcomes.

\section{References}

Agarwala, T. (2003). Innovative human resource practices and organizational commitment: an empirical investigation. The International Journal of Human Resource Management, 14(2), 175197.

Allen, T. D., \& Rush, M. C. (1998). The effects of organizational citizenship behavior on performance judgements: A field study and a laboratory experiment. Journal of Applied Psychology, 83, 247260.

Allen, D. G., Shore, L. M., \& Griffeth, R. W. (2003). The role of perceived organizational support and supportive human resource practices in the turnover process. Journal of Management, 29(1), 99118.

Appelbaum, E., Bailey, T., Berg, P., \& Kalleberg, A. L. (2000). Manufacturing advantage: Why highperformance systems pay off. Ithaca, NY: Cornell University Press.

Argyris, C. (1998). Empowerment: the emperor's new clothes. Harvard Business Review, 76(3), 98106.

Arthur, J. B. (1992). The link between business strategy and industrial relations systems in American steel minimills. Industrial and Labor Relations Review, 45(3), 488-506.

Arthur, J. B. (1994). Effects of human resource systems on manufacturing and turnover. Academy of Management Journal, 37(3), 670-687.

Bateman, T. S., \& Organ, D. W. (1983). Job satisfaction and the good soldier: the relationship between affect and employee "citizenship". Academy of Management Journal, 26, 587-595.

Barnard, C. I. (1938). The Functions of the Executive. Cambridge, MA: Harvard University Press.

Bartel, A. (2004). Human resource management and organisational performance: Evidence from retail banking. Industrial and Labor Relations Review, 57(2), 181-203. 
Beer, M., Spector, B., Lawrence, P. R., Mills, Q. D., \& Walton, R. E. (1984). Managing Human Assets. New York: Free Press.

Blau, P. M. (1964). Exchange and Power in Social Life. New York: Wiley.

Blyton, P., \& Turnbull, P. (1992). HRM: Debates, dilemmas and contradictions. In B. Blyton \& P. Turnbull (Eds.), Assessing Human Resource Management. London: Sage.

Brief, A. P., \& Motowidlo, S. J. (1986). Prosocial organziational behaviors. Academy of Management Review, 11(4), 710-725.

Cappelli, P. (1999). The New Deal At Work: Managing the Market Driven Force. Boston: Harvard Business School Press.

Cappelli, P., \& Neumark, D. (2001). Do "high-performance" work practices improve establishment level outcomes? Industrial and Labor Relations Review, 54(4), 737-775.

Coffey, R. E., Cook, C., \& Hunsaker, P. L. (1994). Management and Organizational Behavior. Burr Ridge, IL: Trwin.

Colarelli, S. M., Dean, R. A., \& Konstans, C. (1987). Comparative effects of personal and situational influences on job outcomes of new professionals. Journal of Applied Psychology, 72, 558-566.

Delaney, J. T., \& Huselid, M. A. (1996). The impact of human resource management practices on perceptions of organizational performance. Academy of Management Journal, 39(4), 949-969.

Den Hartog, D. N., \& Verburg, R. M. (2004). High performance work systems, organisational culture and firm effectiveness. Human Resouce Management Journal, 14(1), 55-78.

Dore, R. P. (1992). Japan's version of managerial capitalism. In A. K. Thomas \& M.

Useem (Eds.), Transforming Organizations (pp. 17-27). New York: Oxford University Press.

Dunham, R. B., Grube, J. A., \& Castaneda, M. B. (1994). Organizational commitment: the utility of an integrative definition. Journal of Applied Psychology, 79, 730-780.

Eisenberger, R., Huntington, R., Hutchison, S., \& Sowa, D. (1986). Perceived organizational support. Journal of Applied Psychology, 71, 500-507.

Eisenberger, R., Fasolo, P., \& Davis-LaMastro, V. (1990). Perceived organizational support and employee diligence, commitment, and innovation. Journal of Applied Psychology, 75(1), 51-59.

Fox, A. (1974). Beyond contract: Work, power and trust relations. London: Faber and Faber.

Gallie, D., Felstead, A., \& Green, F. (2001). Employer policies and organizational commitment in Britain 1992-97. Journal of Management Studies, 38(8), 1081-1101.

Gibb, S. (2001). The state of human resource management: evidence from employees' views of HRM systems and staff. Employee Relations, 23(4), 318-336.

Gould-Williams, J. (2004). The effects of 'high commitment' HRM practices on employee attitude: the views of public sector workers. Public Administration, 82(1), 63-81.

Gouldner, A. W. (1960). The norm of reciprocity: a preliminary statement. American Sociological Review, 25(2), 161-178.

Grant, D., \& Shields, J. (2002). In search of the subject: Researching employee reactions to human resource management. The Journal of Industrial Relations, 44(3), 313-334.

Guest, D. (1999). Human resource management - the workers verdict. Human Resouce Management Journal, 9(3), 5-25.

Guest, D. (2002). Human resouce management, corporate performance and employee wellbeing: Building the worker into HRM. The Journal of Industrial Relations, 44(3), 335-358.

Guest, D., \& Conway, N. (2002). Communicating the psychological contract: An employer perspective. Human Resource Management Journal, 12, 22-38.

Guthrie, J. P. (2001). High-involvement work practices, turnover, and productivity: evidence from New Zealand. Academy of Management Journal, 44(1), 180-190.

Guzzo, R. A., \& Noonan, K. A. (1994). Human resource practices as communications and the psychological contract. Human Resource Management, 33(3), 447-462.

Guzzo, R. A., Noonan, K. A., \& Elron, E. (1994). Expatriate managers and the psychological contract. Journal of Applied Psychology, 79, 617-626.

Hitt, M. A. (1998). Twenty-first century organizations: Business firms, business schools, and the academy. Academy of Management Review, 23(2), 218-224.

Homans, G. (1961). Social Behavior: Its Elementary Forms. New York: Harcourt, Brace and World. 
Ichniowski, C., Shaw, K., \& Prennushi, G. (1997). The effects of human resource management practices on productivity: a study of steel finishing lines. American Economic Review, 87(3), 291313.

Iverson, R. D., \& Buttigieg, D. M. (1999). Affective, normative, and continuance commitment: can the 'right kind' of commitment be managed? Journal of Management Studies, 36(3), 307-333.

Katz, D. (1964). The motivational basis of organizational behavior. Behavioral Science, 9, 131-146.

Katz, D., \& Khan, R. L. (1966). The Social Psychology of Organizations. New York: NY: Wiley.

Kissler, G. D. (1994). The new employment contract. Human Resource Management, 33(3), 335-351.

Kreitner, R., \& Kinicki, R. (1995). Management. Boston: Houghton Mifflin.

Lester, S. W., Turnley, W. H., Bloodgood, J. M., \& Bolino, M. C. (2002). Not seeing eye to eye: difference in supervisor and subordinate perceptions of and attributions for psychological contract breach. Journal of Organizational Behavior, 23(1), 39-56.

Levinson, H., Price, C. R., Munden, K. J., \& Solley, C. M. (1962). Men, Management and Mental Health. Cambridge, Mass: Harvard University Press.

Lievens, F., \& Anseel, F. (2004). Confirmatory factor analysis and invariance of an organizational citizenship behaviour measure across samples in a Dutch-speaking context. Journal of Occupational and Organizational Psychology, 77, 299-306.

MacDuffie, J. P. (1995). Human resource bundles and manufacturing performance: organizational logic and flexible production systems in the world auto industry. Industrial and Labor Relations Review, 48(2), 197-221.

MacKenzie, S. B., Podsakoff, P. M., \& Fetter, R. (1991). Organizational behavior and objective productivity as determinants of managerial evaluations of salespersons' performance. Organizational Behavior and Human Decision Processes, 50, 123-150.

Mathieu, J. E., \& Zajac, D. (1990). A review and meta-analysis of the antecedents, correlates, and consequences of organizational commitment. Psychological Bulletin, 108, 171-194.

McFarlane Shore, L., \& Tetrick, L. F. (1994). The psychological contract as an explanatory framework in the employment relationship. Trends in Organizational Behavior, 1, 91-109.

McLean Parks, J., Kidder, D. L., \& Gallagher, D. G. (1998). Fitting square pegs into round holes: mapping the domain of contingent work arrangements onto the psychological contract. Journal of Organizational Behavior, 19, 697-730.

Meyer, J. P., \& Allen, N. J. (1997). Commitment in the workplace: theory, research, and application. Thousand Oaks: CA: Sage.

Meyer, J. P., Allen, M. J., \& Smith, C. A. (1993). Commitment to organizations and occupations: Extension and test of a three-component conceptualization. Journal of Applied Psychology, 78, 538551.

Meyer, J. P., \& Herscovitch, L. (2001). Commitment in the workplace toward a general model. Human Resource Management Review, 11, 299-326.

Meyer, J. P., \& Smith, C. A. (2000). HRM practices and organizational commitment: Test of a mediation model. Canadian Journal of Administrative Sciences, 17(4), 319-331.

Meyer, J. P., Paunonen, S. V., Gellatly, I. R., Goffin, R. D., \& Jackson, D. N. (1989). Organizational commitment and job performance: it's the nature of the commitment that counts. Journal of Applied Psychology, 74, 152-156.

Millward, L. J., \& Hopkins, L. J. (1998). Psychological contracts, organizational and job commitment. Journal of applied Social Psychology, 28, 1530-1556.

Morrison, E. W., \& Robinson, S. L. (1997). When employees feel betrayed: a model of how psychological contract violation develops. Academy of Management Review, 22(1), 226-256.

Niehoff, B. P., \& Moorman, R. H. (1993). Justice as a mediator of the relationship between methods of monitoring and organizational citizenship behaviors. Academy of Management Journal, 36(3), 527556.

Noer, D. (1993). Healing the wounds; Overcoming the trauma of layoffs and revitalizing downsizing organizations. San Fransisco, CA.: Jossey Bass.

Organ, D. W. (1988a). Organizational citizenship behavior: The good soldier syndrome. Lexington, MA: Lexington Books. Organ, D. W. (1988a). 
Organ, D. W., \& Konovsky, M. (1989). Cognitive versus affective determinants of organizational citizenship behavior. Journal of Applied Psychology, 74(1), 157-164.

Organ, D. W., \& Ryan, K. (1995). A meta-analytic review of attitudinal and dispositional predictors of organizational citizenship behavior. Personnel Psychology, 48(4), 775-802.

Podsakoff, P. M., MacKenzie, S. B., Paine, J. B., \& Bachrach, D. G. (2000). Organizational citizenship behaviors: A critical review of the theoretical and empirical literature and suggestions for future research. Journal of Management, 26(3), 513-563.

Porter, L. W., Steers, R. M., Mowday, R. T., \& Boulian, P. V. (1974). Organizational commitment, job satisfaction, and turnover among psychiatric technicians. Journal of Applied Psychology, 59, 603605.

Purcell, J. (1999). Best practice and best fit: Chimera or cul-de-sac? Human Resouce Management Journal, 9(3), 26-41.

Rhoades, L., \& Eisenberger, R. (2002). Perceived organizational support: a review of the literature. Journal of Applied Psychology, 87(4), 698-714.

Rioux, S. M., \& Penner, L. A. (2001). The causes of organizational citizenship behavior: A motivational analysis. Journal of Applied Psychology, 86, 1306-1314.

Robinson, S. L. (1996). Trust and breach of the psychological contract. Administrative Science Quarterly, 41, 574-599.

Robinson, S. L., \& Morrison, E. W. (1995a). Psychological contracts and OCB: the effect of unfulfilled obligations on civic virtue behavior. Journal of Organizational Behavior, 16(3), 289-298.

Robinson, S. L., \& Rousseau, D. M. (1994). Violating the psychological contract: not the exception but the norm. Journal of Organizational Behavior, 15, 245-259.

Roehling, M. V. (1996). Critical issues in the conceptualization of the psychological contract construct. Paper presented at the annual meeting of Academy of Management, Cincinnati.

Rousseau, D. M. (1989). Psychological and implied contracts in organizations. Employee Responsibilities and Rights Journal, 2, 121-139.

Rousseau, D. M. (1990). New hire perceptions of their own and their employer's obligations: A study of psychological contracts. Jounal of Organizational Behavior, 11, 389-400.

Rousseau, D. M. (2001a). Schema, promise, and mutuality: The building blocks of the psychological contract. Journal of Occupational and Organizational Psychology, 74, 511-541.

Rousseau, D. M., \& Greller, M. M. (1994). Human resource practices: administrative contract makers. Human Resouce Management, 3, 385-401.

Rousseau, D. M., \& McLean Parks, J. M. (1993). The contracts of individuals and organizations. In L. L. Cummings \& B. M. Staw (Eds.), Research in Organizational Behaviour (Vol. 15, pp. 1-43). Greenwich: JAI Press.

Rousseau, D. M., \& Tijoriwala, S. A. (1998). Assessing psychological contracts: issues, alternatives and measures. Jounal of Organizational Behavior, 19, 679-695.

Sels, L., Janssens, M., \& Van Den Brande, I. (2004). Assessing the nature of psychological contracts: a validation of six dimensions. Journal of Organizational Behavior, 25, 461-488.

Shore, L. M., \& Wayne, S. J. (1993). Commitment and employee behavior: comparison of affective commitment and continuance commitment with perceived organizational support. Journal of Applied Psychology, 78(5), 774-780.

Smith, C. A., Organ, D. W., \& Near, J. P. (1983). Organizational citizenship behavior: Its nature and antecedents. Journal of Applied Psychology, 68(4), 655-663.

Snell, S., \& Dean, J. (1992). Integrated manufacturing and human resource management: a human capital perspective. Academy of Management Journal, 35(3), 467-504.

Stanley, D. J., Meyer, J. P., Topolnytsky, L., \& Herscovitch, L. (1999, May). Affective, continuance and normative commitment: meta-analyses of interrelations and outcomes. Paper presented at the Paper presented at the annual meeting of the Society for Industrial/Organizational Psychology.

Tett, R. P., \& Meyer, J. P. (1993). Job satisfaction, organizational commitment, turnover intention, and turnover: Path analysis based on meta-analytic findings. Personnel Psychology, 46, 259-293. 
Turnley, W. H., Bolino, M. C., Lester, S. W., \& Bloodgood, J. M. (2003). The impact of psychological contract fulfillment on the performance of in-role and organizational citizenship behaviors. Journal of Management, 29(2), 187-206.

Walton, R. A. (1985). From control to commitment in the workplace. Harvard Business Review, 63(2), 77-84.

Weakland, J. H. (2001). Human resources holistic approach to healing downsized survivors. Organization Development Journal, 19(2), 59-69.

Whitener, E. M. (2001). Do "high commitment" human resource practices affect employee commitment? A cross-level analysis using hierarchical linear modeling. Journal of Management, 27, 515-535.

Wood, S., \& de Menezes, L. (1998). High commitment management in the UK: evidence from the Workplace Industrial Relations Survey and Employers' Manpower and Skills Practices Survey. Human Relations, 51(4), 485-515.

Wright, P., McMahan, G. C., \& McWilliams, A. (1994). Human resources and sustained advantage: A resource-based perspective. International Journal of Human Resource Management, 5(2), 301-326.

Youndt, M. A., Snell, S., Dean, \& Lepak, D. (1996). Human resource management manufacturing strategy, and firm performance. Academy of Management Journal, 39(4), 836-866. 